\title{
Purification and Characterization of a Noble Thermostable Alpha-amylase from Anoxybacillus tengchongensis RA1-2-1 Isolated from Geothermal Spring of Nepal PARASH MANI TIMILSINA ${ }^{1}$, GYANU RAJ PANDEY $Y^{1,2}$, ASMITA SHRESTHA, ${ }^{2}$ MANISH OJHA $^{1}$, GARIMA BARAL ${ }^{1}$, TIKA BAHADUR KARKI ${ }^{1}$ \\ ${ }^{1}$ Department of Biotechnology, Kathmandu University, Dhulikhel, 6250, Nepal \\ ${ }^{2}$ Biotechnological Research and Developmental Centre Pvt. Ltd., Bharatpur, Chitwan, 44200, Nepal
}

\begin{abstract}
A thermophilic amylolytic strain, Anoxybacillus tengchongensis RA1-2-1 was isolated from geothermal spring of Rasuwagadi district of Nepal. The BLAST alignment of the 16s rRNA sequence revealed $99.3 \%$ similarity with the type strain Anoxybacillus tengchongensis T-11. The morphological, physiological and biochemical properties were similar to the type strain. The enzyme from the strain was purified to 21-fold purification by DEAE-cellulose ion exchange chromatography. The $K_{m}$ value of the enzyme was $0.68 \pm 0.05 \mathrm{mg} / \mathrm{ml}$. The optimum $\mathrm{pH}$ and temperature were 7.0 and $70{ }^{\circ} \mathrm{C}$. SDS-PAGE analysis showed a single band at $69 \mathrm{kDa}$. The half-life of the enzyme at $70^{\circ} \mathrm{C}$ and $80^{\circ} \mathrm{C}$ were $85.01 \mathrm{~min}$ and $51.96 \mathrm{~min}$ respectively. TLC analysis of the hydrolysis product showed that the enzyme is maltogenic amylase. The calcium independent enzyme was completely inhibited by $\mathrm{Hg}^{2+}$ but showed inhibitory effect in the range of $100 \%-30 \%$ in the presence of other salts at 1-10mM concentrations.
\end{abstract}

Key words: Alpha-amylase, Enzyme Kinetics, Thermostability, Liquefaction, Starch

\section{Introduction}

Extremophilic microorganism that can survive harsh environmental conditions can be a potential source of industrially important enzymes. Enzymes from this extremophile have unique properties of salt tolerance, thermostability, cold adaptability and substrate specificity (Dumorné et al., 2017).

Halophilic thermophiles isolated from geo thermal springs are a potential source of noble enzymes. Hydrolytic enzymes such as amylase, protease and lipase with noble properties have been identified in thermophiles isolated from geothermal springs. Studies have been focused on the identification of these enzymes with noble properties suitable of specific application in food chemical, pharmaceuticals and biomass energy.

Alpha-amylase (EC 3.2.1.1, $\alpha$-D-Glucan-glucanohydrolase) is one of the most important enzymes which has application in brewing, baking, textile, detergent and bioethanol production (Kindle, 1983; Finore et al; 2011; Fincan \& Enez, 2014). Noble alpha-amylase with greater range of $\mathrm{pH}$ and temperature stability, tolerance to metal inhibition and higher substrate affinity has been isolated from thermophiles isolated geothermal springs.

Anoxybacillus tengchogensis was first isolated by zhang et al from tengchong hot springs of China (Zhang et al., 2011). In this study, a highly amylolytic A. tengchongensis RA1-2-1 strain was isolated from Rasuwagadi geothermal spring sediment of Nepal. Preliminary medium screening was done to identify optimum production medium. The enzyme was purified and characterized. Alpha-amylase from $A$. tengchongensis RA1-2-1 was found to be a potential candidate for industrial application. Owing to the high thermostability and resistance to metal inhibition, the enzymes can be used to improve the existing process for liquefaction in food processing industries.

*Corresponding author, email address: timipara@ku.edu.np

\section{Materials and Methods Materials}

All bacteriological grade growth medium and reagents were purchased from Himedia. All Analytical reagents for enzyme assay (Sodium phosphate, monobasic, Sodium chloride, Potato Starch,Sodium hydroxide, Potassium sodium tartrate, tetrahydrate, 3,5-Dinitrosalicylic acid, D-(+)-Maltose ) were purchased from Sigma-Aldrich.

\section{Sample collection and isolation}

Samples were collected from geothermal springs located in Rasuwagadi district of Nepal. Water, bio mats and sediments were collected using three bottles of $500 \mathrm{ml}$ sterile thermo flask and transported to the laboratory within 24 hours in icebox.

Enrichment of thermophiles was done in nutrient broth $(\mathrm{pH}$ 7.0 ) at $55^{\circ} \mathrm{C}$ water-bath. Growth was monitored by measuring turbidity with a DEN-B densitometer. Isolation of obligate thermophiles was performed by incubation of $1: 3(\mathrm{v} / \mathrm{v})$ dilution homogeneous bacterial suspension at $70{ }^{\circ} \mathrm{C}$ corresponding to temperature of the sample site. The culture that showed positive growth was inoculated in nutrient broth at $37^{\circ} \mathrm{C}$. The culture that showed growth at $70{ }^{\circ} \mathrm{C}$ but do not show significant growth at $37{ }^{\circ} \mathrm{C}$ was screened for amylase activity. Alpha amylase activity was tested by streaking the pure culture in $1 \%$ starch agar plates. The amylolytic activity was detected by the formation of clear zone around the isolates after addition of Lugol's iodine.

\section{Characterization of the isolates}

The amylolytic strain was characterized by phenotypic, physiological and molecular study. The phenotypic study investigated were colony morphology, grams staining, spore staining and microscopic observations.

The physiological parameters studied were: optimum growth temperature, optimum $\mathrm{pH}$, optimum salt tolerance and motility test. Optimum temperature, $\mathrm{pH}$ and salt concentration 
were obtained by OVAT (one variable at a time) method. For determination of optimum temperature, $0.5 \mathrm{ml}$ overnight culture was transferred to $5 \mathrm{ml}$ fresh nutrient broth in $15 \mathrm{ml}$ tubes. The tubes were incubated at $40{ }^{\circ} \mathrm{C}, 50^{\circ} \mathrm{C}, 60{ }^{\circ} \mathrm{C}, 70^{\circ} \mathrm{C}$ and $80{ }^{\circ} \mathrm{C}$ in orbiter shaker at $150 \mathrm{rpm}$. The optical density readings were taken every hour. For determination of optimum $\mathrm{pH}$, the temperature was maintained at previously identified temperature optimum and inoculated in nutrient broth of pH 6.0-11.0 at 0.5-unit increment. For determination of optimum salt tolerance, overnight log phase culture was transferred to $5 \mathrm{ml}$ nutrient broth with final $\mathrm{NaCl}$ concentrations of $0 \%, 1 \%, 2 \%, 3 \%, 4 \%$ and $5 \%$. OD reading was done in one-hour interval. Maximum specific growth rate was estimated by Gompertz growth model nonlinear regression method (Zwietering et al., 1990).

All carbohydrate utilization test was done in replicates using Himedia HiCarbo ${ }^{\mathrm{TM}}$ identification kits. Antibiotic sensitivity test for 16 different antibiotics was done with Himedia $\mathrm{HiComb}^{\mathrm{TM}}$ disc according to the manual.

\section{Molecular characterization}

Molecular characterization of the strain was done by $16 \mathrm{~s}$ rRNA sequence analysis. Genomic DNA was isolated using DNeasy Ultraclean Microbial Kit Qiagen. PCR amplification was performed using $27 \mathrm{~F}$ and $1492 \mathrm{R}$ universal primers. The PCR product was purified by Qiagen QIAquick PCR purification kit. The PCR product was sequenced in ABI Prism DNA sequencer (Macrogen, Korea) using Big Dye terminator cycle sequencing. Sequencing primers used were $785 \mathrm{~F}$ and $907 \mathrm{R}$ primers. The forward and reverse sequence obtained was analysed and consensus sequence was generated in Mega-X. The FASTA sequence was analysed in NCBI blast tool. The phylogenetic tree was constructed using neighbour Joining algorithm. The sequence was published in NCBI GenBank.

\section{Determination of amylase assay}

The activity of alpha-amylase was assayed according to Bernfeld et al (Bernfeld, 1955). The unit of alpha-amylase is defined as the amount of enzyme which liberates $1 \mathrm{mg}$ of reducing sugar as maltose in 3 min under the assay condition. Bacillus amyloliquefaciens alpha-amylase was used for test validation. Maltose released ( $\mathrm{mg}$ ) in the amylase test solution is calculated by linear regression analysis of the standard maltose curve. Protein concentration in the enzyme sample is measured by Lowry's assay (Lowry et al., 1951).

Units $/ \mathrm{ml}$ enzyme $=(\mathrm{mg}$ of maltose released $) *$ Dilution factor Units $/ \mathrm{mg}$ protein $=(\mathrm{Units} / \mathrm{ml}$ enzyme $) /(\mathrm{mg} / \mathrm{ml}$ protein $)$

\section{Selection of medium for enzyme production}

The bacteria were cultured in $100 \mathrm{ml}$ volume in predefined five different basal medium M1 (Upton \& Fogarty, 1977), M2, M3 (Pfueller \& Elliott, 1969), M4 (Andersson et al., 1985) and M5 (Upton \& Fogarty, 1977)] and incubated at 55 ${ }^{\circ} \mathrm{C}$. Medium M1 had the following composition(grams per liter) : Corn starch, 15.0; $\mathrm{CaCl}_{2} \cdot \mathrm{H}_{2} \mathrm{O}, 1.0 ; \mathrm{MgCl}_{2} .6 \mathrm{H}_{2} \mathrm{O}, 1.0$; $\mathrm{K}_{2} \mathrm{HPO}_{4}, 4.0 ;\left(\mathrm{NH}_{4}\right)_{2} \mathrm{SO}_{4}, 1.0$; and trace metal solution $10 \mathrm{ml}$ of composition(milligram per liter) : $\mathrm{CuSO}_{4} .5 \mathrm{H}_{2} \mathrm{O}, 16.0$; $\mathrm{FeSO}_{4} .7 \mathrm{H}_{2} \mathrm{O}, 100.0 ; \mathrm{ZnSO}_{4} .7 \mathrm{H}_{2} \mathrm{O}, 80.0 ; \mathrm{MnCl}_{2} .4 \mathrm{H}_{2} \mathrm{O}, 7.0$; $\mathrm{pH}$ adjusted to 7.0 after autoclaving. Medium M2 had the following composition (gram per liter): Corn starch, 10.0; Yeast extract, 3.0; Peptone, 5.0; $\mathrm{CaCl}_{2} .2 \mathrm{H}_{2} \mathrm{O}, 0.25 .0 . \mathrm{pH}$ adjusted to 7.0 after autoclaving. Medium $\mathbf{M 3}$ had the following composition (gram per liter ): Casein Hydrolysate, 5.0; Yeast Extract, 0.5; $\mathrm{K}_{2} \mathrm{HPO}_{4}, 3.0 ; \mathrm{KH}_{2} \mathrm{PO}_{4}, 1.0$; Soluble starch, 1.0; Trace metal $10 \mathrm{ml}$ of the composition (grams per liter ): $\mathrm{FeCl}_{3}, 0.3 ; \mathrm{MgCl}_{2} .6 \mathrm{H}_{2} \mathrm{O}, 0.5 ; \mathrm{CaCl}_{2} .6 \mathrm{H}_{2} \mathrm{O}, 0.85$; $\mathrm{NH}_{4} \mathrm{Cl}, 100.0 ; \mathrm{NaCl}, 100.0 . \mathrm{pH}$ adjusted to 7.3 after autoclaving. Medium M4 had the following composition (grams per liter): Soluble starch, 10.0; Peptone, 5.0; Yeast extract, 2.0; $\mathrm{NaCl}, 15.0 ; \mathrm{KH}_{2} \mathrm{PO}_{4}, 0.5 ; \mathrm{MgSO}_{4} .7 \mathrm{H}_{2} \mathrm{O}, 0.5$; $\mathrm{CaCl}_{2}, 0.1$; Sterile glycerol, $15 \% \mathrm{v} / \mathrm{v}$. Medium M5 had the following composition (grams per liter) : Bacterial peptone, 5.0, Corn starch, 20.0; $\mathrm{K}_{2} \mathrm{HPO}_{4}, 2.0 ; \quad\left(\mathrm{NH}_{4}\right)_{2} \mathrm{SO}_{4}, 5.0$; $\mathrm{MgSO}_{4} .7 \mathrm{H}_{2} \mathrm{O}, 1.0$; Sodium lactate, 8.0; $\mathrm{CaCO}_{3}, 2.0$; Inositol, 0.01; Trace metals: same as in medium M1. $\mathrm{pH}$ was adjusted to 7.0. The cell free medium after centrifugation was tested for amylolytic activity by amylase assay. The medium with highest amylolytic activity was chosen as basal medium for enzyme production in $300 \mathrm{ml}$ medium.

\section{Purification of amylase}

The production medium was centrifuged at $8,400 \mathrm{~g}$ for $15 \mathrm{~min}$ to separate cells and particulate matters. The supernatant was collected. Ammonium sulphate was added to the culture supernatant to get $75 \%$ saturation level. All precipitation work was performed at $4{ }^{0} \mathrm{C}$. The precipitated solution was centrifuged at $21000 \mathrm{~g}$ for $15 \mathrm{~min}$ at $4{ }^{\circ} \mathrm{C}$. The pellet was dissolved in $1 \mathrm{ml}$ of $0.01 \mathrm{mM}$ phosphate buffer, $\mathrm{pH} 7.0$. Overnight dialysis was performed using 12,000 MW cut-off dialysis bags against $0.01 \mathrm{M}$ phosphate buffer with three changes of the same buffer. The dialyzed solution was purified in DEAE cellulose mini column. The column was washed with $0.01 \mathrm{M}$ phosphate buffer. Enzyme solution was added slowly and again washed with the same buffer. The enzyme was eluted with $1 \mathrm{M} \mathrm{NaCl}$ with a flow rate of $1 \mathrm{ml}$ per min and fractions of $1 \mathrm{ml}$ each was collected. All the fractions were analysed by amylase assay at $55^{\circ} \mathrm{C}$ and $\mathrm{pH}$ 7.0. Three fractions with the highest amylase activity were collected and dialyzed against $0.1 \mathrm{M}$ phosphate buffer overnight and freeze-dried. (Telstar Lyoquest). Denaturing SDS-PAGE of the purified enzyme was performed according to Laemmli (Laemmli, 1970) for determination of molecular weight and purity of the enzyme. The gel image was analysed by GelAnalyzer 19.1.

\section{Determination of optimum temperature and $\mathrm{pH}$ Effect of temperature}

The effect of temperature on amylase activity was measured from $30{ }^{\circ} \mathrm{C}$ to $100{ }^{\circ} \mathrm{C}$ at $\mathrm{pH}$ 7.0. The activity of appropriately diluted stock enzyme solution was measured by amylase assay as mentioned earlier but the incubation temperature was varied accordingly. Relative activity was calculated by taking percentage ratio against the highest activity observed. The optimum temperature was determined from the plot of temperature vs relative activity.

\section{Effect of pH}

The effect of $\mathrm{pH}$ on the alpha amylase activity was performed in the $\mathrm{pH}$ range of $3.0-9.0$. The activity of diluted stock enzymes was measured by amylase assay. The starch solution was prepared in different $\mathrm{pH}$ adjusted buffers. The buffers used were: $20 \mathrm{mM}$ Sodium acetate $(\mathrm{pH} 3.0$ - 5.0), $20 \mathrm{mM}$ Sodium phosphate (pH 5.0 - 7.5) and $20 \mathrm{mM}$ Tris- $\mathrm{HCl}$ buffer (pH 8.0 - 9.5). 


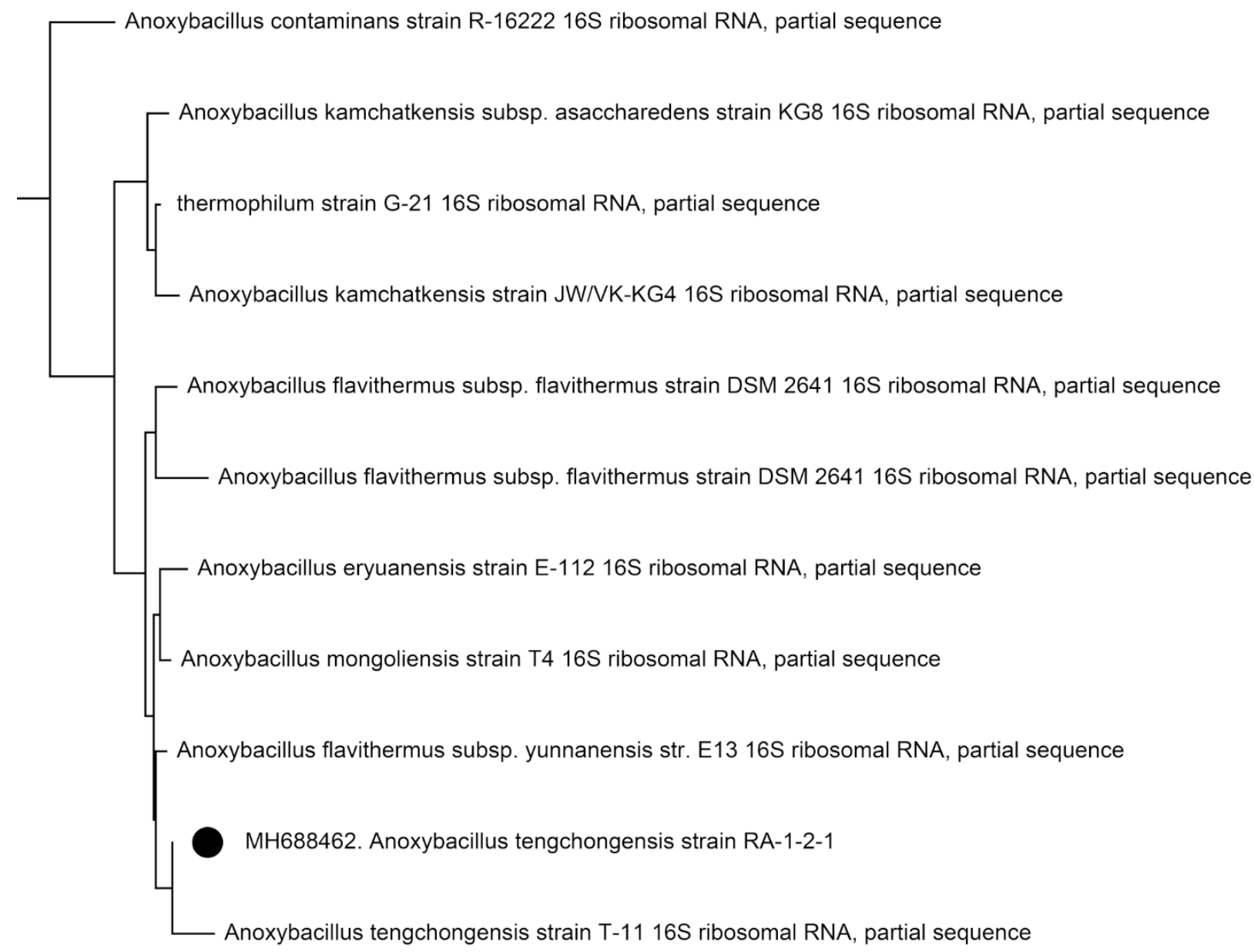

Anoxybacillus tengchongensis strain T-11 $16 \mathrm{~S}$ ribosomal RNA, partial sequence

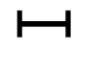

0.0050

Fig. 1. Phylogenetic tree of strain RA1-2-1 isolate with 99.3\% homology with Anoxybacillus tengchongensis T-11 type strain. The tree was constructed using neighbor joining algorithm in rRNA database using NCBI blast tool.

\section{Thermo-stability Study}

The thermostability of the enzyme was studied at $60{ }^{\circ} \mathrm{C}, 70$ ${ }^{\circ} \mathrm{C}$ and $80{ }^{\circ} \mathrm{C} .10 \mathrm{ml}$ of the appropriately diluted enzyme solution in phosphate buffer $\mathrm{pH} 7.0$ was transferred in test tubes and incubated in water bath. The residual activity of the enzyme was calculated after 1, 2, 3 and 4 hours of incubation by amylase assay at $\mathrm{pH} 7.0$ and $55^{\circ} \mathrm{C}$. Enzyme activity is compared with the activity at time 0 as $100 \%$. The data was fit into exponential function using Minitab19.0 to calculate half-life.

Thin layer chromatography of hydrolysis product

TLC of the hydrolysis product was performed according to Hansen, 1975 (Hansen, 1975). The product liberated by the action of amylase on starch was identified by spotting the starch digest and standard sugars (glucose, maltose and maltotrioses) on a pre-coated silica plate activated at $110{ }^{\circ} \mathrm{C}$. The plates were developed in butanol: ethanol: water solvent (5:3:2) and dried overnight at room temperature. The individual sugars were visualized with aniline-diphenylamine reagent.

\section{Determination of kinetic parameters and data analysis}

The kinetic parameter $\mathrm{V}_{\max }$ and $\mathrm{K}_{\mathrm{m}}$ is determined by incubating the amylase with final concentration of soluble starch ranging from $0.1 \%$ to $0.7 \%$ in the buffer at optimum $\mathrm{pH}$ and temperature. The enzyme activity is measured by amylase assay as mentioned earlier. The Michaelis-Menten enzyme kinetic model was used for parameter estimation. The kinetic parameter $\mathrm{V}_{\max }$ and $\mathrm{K}_{\mathrm{m}}$ is determined by nonlinear regression statistical methods using Minitab 19.

\section{Enzyme inhibition by metals ions}

The stock enzyme solution was added to equal volume of $2 \mathrm{X}$ metal solutions to make final concentration of $1 \mathrm{mM}$ and 10 $\mathrm{mM}$ respectively. The salt solution used were $\mathrm{BaCl}_{2}, \mathrm{CaCl}_{2}$, $\mathrm{CoCl}_{2}, \mathrm{CuSO}_{4}, \mathrm{FeSO}_{4}, \mathrm{HgCl}_{2}, \mathrm{KCl}, \mathrm{MgSO}_{4}, \mathrm{MnSo} 4, \mathrm{NiCl}_{2}$, $\mathrm{Pb}(\mathrm{C} 2 \mathrm{H} 3 \mathrm{O} 2)_{2}, \mathrm{SnCl}_{2}$ and $\mathrm{ZnSO}_{4}$. The activity of diluted enzyme was measured by amylase assay at optimum temperature and $\mathrm{pH}$. 
Table 1

Taxonomical Characterization of $A$. tengchongensis RA1-2-1.

\begin{tabular}{|c|c|c|}
\hline Test & Study & Results \\
\hline \multirow{2}{*}{ Morphology } & Microscopic study & Gram positive, rods, subterminal endospores \\
\hline & $\begin{array}{l}\text { Colony morphology }(48 \text {-hour } \\
\text { incubation on Nutrient broth } \\
\left., 55^{\circ} \mathrm{C}\right)\end{array}$ & $\begin{array}{l}\text { Circular, pale yellow colour, Entire/lobed margin, Flat elevation, } \\
\text { translucent with dot like appearance in the centre ,2-2.5 mm } \\
\text { diameter }\end{array}$ \\
\hline \multirow[t]{3}{*}{ Physiological test } & Growth on Nutrient broth & $\begin{array}{l}\text { Optimum temperature } 50{ }^{\circ} \mathrm{C} \text {, Optimum } \mathrm{pH} 8.0 \text {, Optimum salt } \\
\text { tolerance } 1 \%\end{array}$ \\
\hline & Motility in SIM agar & Motile \\
\hline & Other physiological tests & $\begin{array}{l}\text {-ve: voges-proskauer test), gas from fermentation (TSI), } \\
\text { phenylalanine deaminase, } \\
\text { +ve: nitrate reduction, catalase, oxidase, anaerobic growth } \\
\text { +ve starch, tributyrin, cellulose, gelatin, } \\
\text {-ve urea, casein, protease, esculin }\end{array}$ \\
\hline \multirow{3}{*}{ Biochemical Test } & Acids from Sugar & $\begin{array}{l}\text { +ve: maltose, fructose, dextrose, raffinose, galactose, trehaloes, } \\
\text { melibiose, sucrose, mannose, inulin } \\
\text {-ve: lactose, xylose, L-arabinose, sodium gluconate, pyruvate }\end{array}$ \\
\hline & $\begin{array}{l}\text { Utilization of carbohydrates } \\
\text { and derivatives }\end{array}$ & $\begin{array}{l}\text { +ve: glycerol, salicin, dulcitol, mannitol, esculin, sorbitol, } \\
\text { pyruvate, erythritol }\end{array}$ \\
\hline & Antibiotic sensitivity assay & 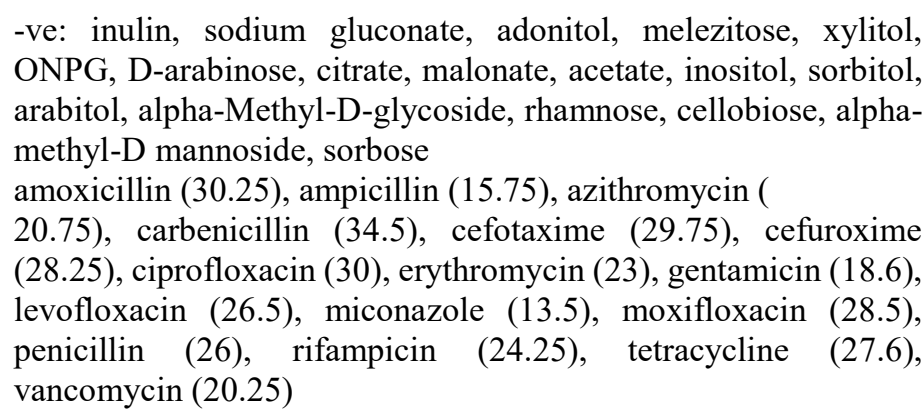 \\
\hline $\begin{array}{l}\text { Molecular } \\
\text { Characterization }\end{array}$ & $\begin{array}{l}16 \mathrm{~s} \text { sequence analysis } \\
\text { (PCR Primers: } 27 \mathrm{~F} \text {, } \\
\text { 1492R) }\end{array}$ & 99.3\% similarity with Anoxybacillus tengchongensis T11 \\
\hline
\end{tabular}

\section{Results}

\section{Sampling and isolation}

Water samples, algal bio mats and sediments were collected from Rasuwagadi geothermal springs of Nepal. The maximum temperature of the water sample was $72^{\circ} \mathrm{C}$ and $\mathrm{pH}$ 7.0. A total of 15 strains were isolated based on colony morphology in nutrient agar plates. Strain RA1-2-1 showed significant amylase activity in starch agar plate's assay.

\section{Characterization}

\section{Molecular characterization}

The 16s partial sequence Blast analysis of strain RA1-2-1 sequence showed $99.3 \%$ homology with the type strain Anoxybacillus tengchongensis T-11. The sequence was published in NCBI gene database with the gene accession no. MH688462. The phylogenetic tree was constructed using Neighbour Joining algorithm using NCBI Blast tool (Fig. 1).

\section{Morphological, physiological and biochemical properties} A. tengchongensis RA1-2-1 was gram positive motile rods with charactertics similar to type strain A. tengchongensis T11. Morphological, physiological and biochemical properties of A. tengchongensis RA1-2-1 are shown in (Table 1). The properties of $A$. tengchongensis RA1-2-1 was similar to $A$. tengchongensis $\mathrm{T}-11$. The optimal $\mathrm{pH}$, temperature and salt concentration were found to be $8.0,50{ }^{\circ} \mathrm{Cd} 1 \%$ respectively. The generation time in the optimal condition was $58.39 \mathrm{~min}$ (Fig. 2).

\section{Medium selection and purification of enzyme}

The maximum amylase activity was observed in Medium M3 $(1.07 \pm 0.05 \mathrm{Units} / \mathrm{ml})$. The enzyme expression in medium M4 and M5 $(0.627 \pm 0.01$ and $0.25 \pm 0.07 \mathrm{U} / \mathrm{ml})$ respectively while the enzyme production in medium M1 and M2 was insignificant (Fig. 3). The enzyme from medium M3 was purified to 21-fold purification after DEAE-Cellulose anion exchange chromatography. The elution pattern showed major peak of amylase activity for three fractions, which were, collected (Fig. 4a). The purified fraction was further subjected to SDS-PAGE analysis for determination of, molecular weight. A single peak of the enzyme at $69 \mathrm{kDa}$ was obtained (Fig. 4b). The specific activity of the purified enzyme was $66.51 \mathrm{U} / \mathrm{mg}$ protein. The final yield was $46 \%$ (Table 2). 

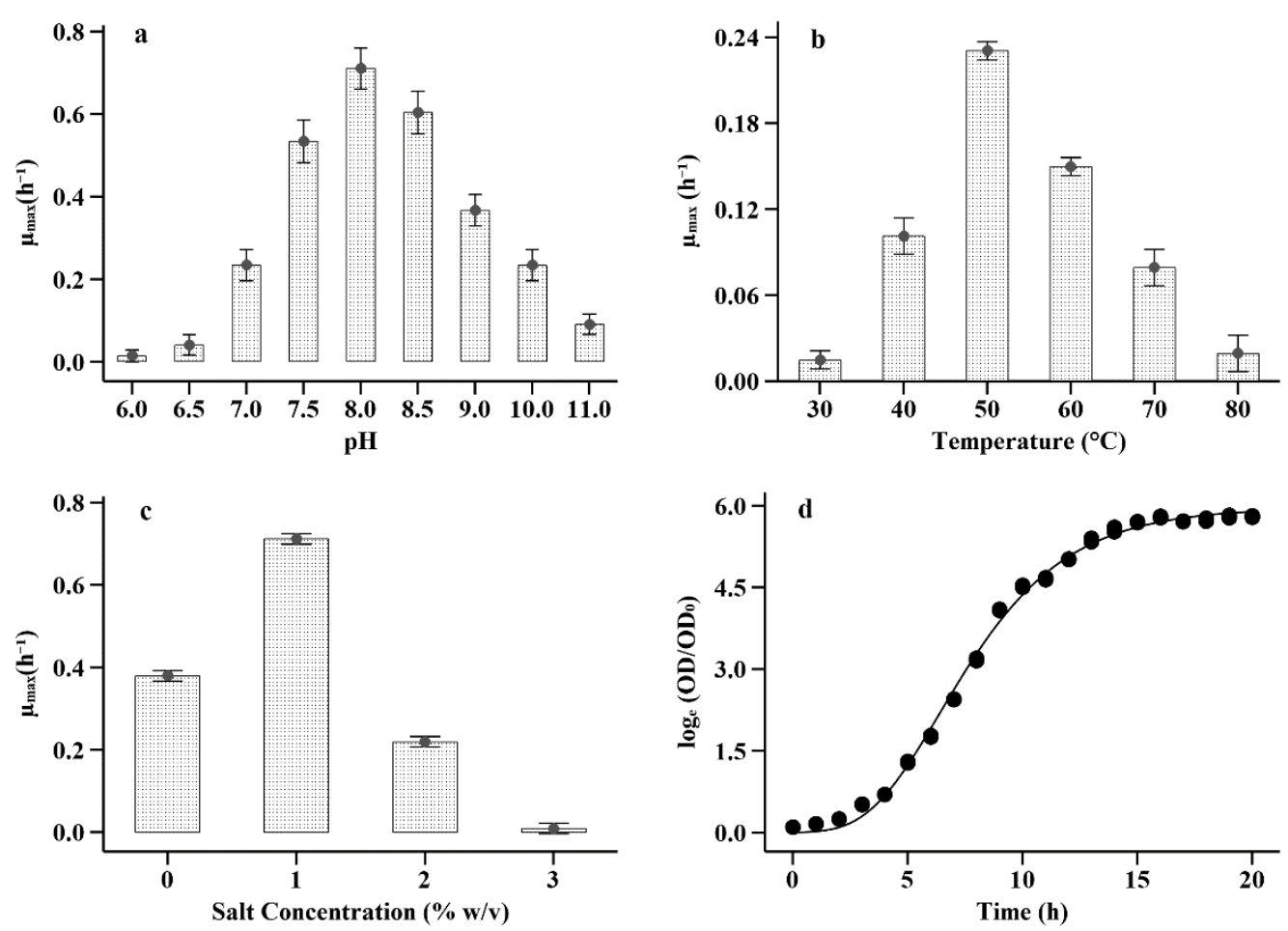

Fig. 2. Growth parameter optimization for A. tengchongensis RA1-2-1 in nutrient broth. A: Maximum specific growth $\operatorname{rate}\left(\mu_{\max }\right)$ at different temperature. B: Maximum specific growth rate $\left(\mu_{\max }\right)$ at $50{ }^{\circ} \mathrm{C}$ and different $\mathrm{pH}$. C: Maximum specific growth rate $\left(\mu_{\max }\right)$ at $\mathrm{pH} 7.0$, temperature $50{ }^{\circ} \mathrm{C}$ and different salt concentrations. D: Gompertz plot of optical density (OD) at different time interval.

\section{Optimization of $\mathrm{pH}$ and temperature}

The optimum $\mathrm{pH}$ was found to be at $\mathrm{pH} 7.0$ (Fig. 5a). The enzyme had activity $38.03 \pm 2.27 \%$ at $\mathrm{pH}$ of 6.0 but higher retention value of $59.68 \pm 0.63 \%$ in $\mathrm{pH} 8.0$. The enzyme retention was $26.6 \pm 0.73 \%$ at $\mathrm{pH} 9.0$. The optimum temperature of the enzyme was found to be at $70{ }^{\circ} \mathrm{C}$. However, the enzyme retained $96.90 \pm 1.4 \%$ at $60{ }^{\circ} \mathrm{C}, 80.72$ $\pm 0.68 \%$ at $80{ }^{\circ} \mathrm{C}$ and and $37.00 \pm 3.1 \%$ at $90{ }^{\circ} \mathrm{C}$ (Fig. 5b). The data suggest the highly thermophillic nature of the enzyme.

Thermostability study and determination of kinetic parameter

The thermal stability of the enzyme was calculated at 60 ${ }^{\circ} \mathrm{C}, 70{ }^{\circ} \mathrm{C}$ and $80{ }^{\circ} \mathrm{C}$. The enzyme half-life at $60{ }^{\circ} \mathrm{C}, 70{ }^{\circ} \mathrm{C}$ and $80{ }^{\circ} \mathrm{C}$ were calculated to be $157.6 \mathrm{~min}, 85.01 \mathrm{~min}$ and 51.96 min respectively (Fig. 6). The $\mathrm{K}_{\mathrm{m}}$ and $\mathrm{V}_{\max }$ value were calculated at optimum temperature and $\mathrm{pH}$ using nonlinear regression method in Minitab. The Michalis Menten constant
$\left(\mathrm{K}_{\mathrm{m}}\right)$ was $0.68 \pm 0.04 \mathrm{mg} / \mathrm{ml}$ and $\mathrm{V}_{\max }$ value was $2.12 \pm 0.02$ $\mathrm{mM}($ maltose $) / \mathrm{min}$ (Fig. 7).

\section{Thin layer chromatography}

To characterize the mode of action of the alpha-amylase, the hydrolysis products were analysed by thin layer chromatography. Soluble starch was converted into glucose, maltose and maltotriose (Fig. 8). After $1 \mathrm{~h}$ of incubation, all hydrolysis product was present. The dominant product was maltose as darker spot in the maltose zone suggesting maltogenic amylase. This suggests that the alpha-amylase of A. tengchongensis RA1-2-1- is a maltogenic amylase.

\section{Metal inhibition assay}

The amylase did not require any specific ion for catalytic activity. A stronger inhibitory effect was observed in the presence of $\mathrm{Hg}^{2+}$ at both $1 \mathrm{mM}$ and $10 \mathrm{mM}$ (Fig. 9). All enzyme except $\mathrm{Hg}^{2+}$ showed very small inhibition at $1 \mathrm{mM}$.

Table 2

Purification of alpha-amylase from A. tengchongensis RA 1-2-1.

\begin{tabular}{lllllll}
\hline \multicolumn{1}{c}{ Steps } & $\begin{array}{l}\text { Volume } \\
(\mathbf{m l})\end{array}$ & $\begin{array}{l}\text { Activity } \\
(\mathbf{U})\end{array}$ & $\begin{array}{l}\text { Total } \\
(\mathbf{m g})\end{array}$ & Protein & $\begin{array}{l}\text { Specific } \\
\text { Activity } \\
\text { (U/mg) }\end{array}$ & $\begin{array}{l}\text { Purification } \\
\text { Fold }\end{array}$ \\
\hline Broth Supernatant & 281 & $421.5 \pm 0.9$ & $253.46 \pm 0.6$ & $1.66 \pm 0.04$ & 1 & $\begin{array}{l}\text { Yield } \\
(\%)\end{array}$ \\
Precipitation/Dialysis & 1 & $265.54 \pm .8$ & $11.23 \pm 0.1$ & $23.63 \pm 0.06$ & 14 & 100 \\
$\begin{array}{l}\text { DEAE-Cellulose } \\
\text { Chromatography }\end{array}$ & 3 & $103.89 \pm 0.6$ & $2.91 \pm 0.04$ & $35.39 \pm 0.5$ & 21 & 63 \\
\hline
\end{tabular}




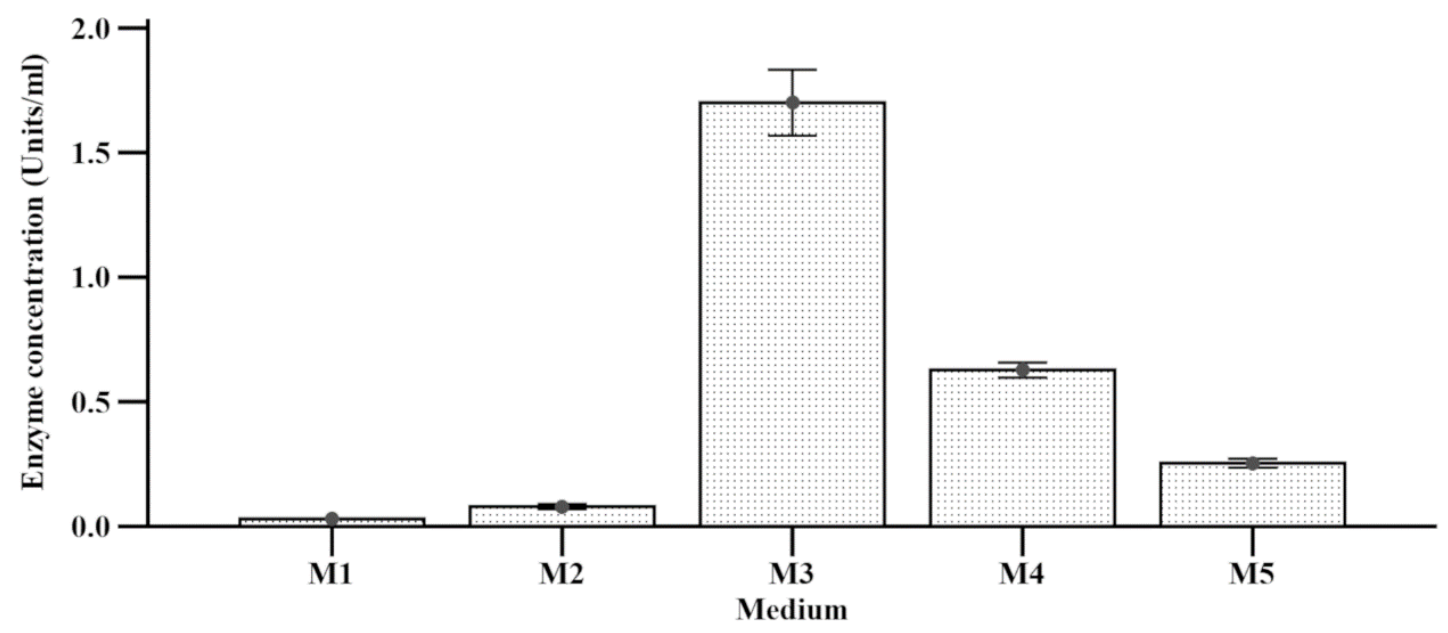

Fig. 3. Amylase activity of medium supernatants after 48 -hour incubation

\section{Discussions}

An obligate thermophile A. tengchongensis RA1-2-1 was isolated from Rasuwagadi geothermal spring of Nepal. The strain showed positive amylolytic activity in starch agar plate. The morphological physiological and biochemical properties of A. tengchongensis RA1-2-1 and type strain $A$. tengchongensis T11 (zhang et al) were similar. Both were gram positive, sporulating rods. The colony characteristics of both strains were similar: circular pale-yellow, flat and opaque after 24-hour incubation in nutrient broth. Both strains have optimum temperature of $50{ }^{\circ} \mathrm{C}$ while closely associated A. flavithermus DSM2641 ${ }^{\mathrm{T}}$ (Heinen et al., 1982) have temperature optimum of $60-65^{\circ} \mathrm{C}$. Optimum $\mathrm{pH}$ for growth of $A$. tengchongensis RA1-2-1 was 8.0 while of $A$. tengchongensis $\mathrm{T} 11$ was 8.5 suggesting both were alkalophilic. Both were positive for catalase and oxidase, gelatine hydrolysis and nitrate reduction test. These tests were negative for $A$. flavithermus DSM $2641^{\mathrm{T}}$ as described by Heinen. BLAST analysis showed that the $16 \mathrm{~s}$ rRNA sequence of A. tengchongensis RA1-2-1 was $99.3 \%$ similar with the type strain. The morphological, physiological, biochemical and molecular data showed that the isolated bacterial culture is a new strain of Anoxybacillus tengchogensis. a

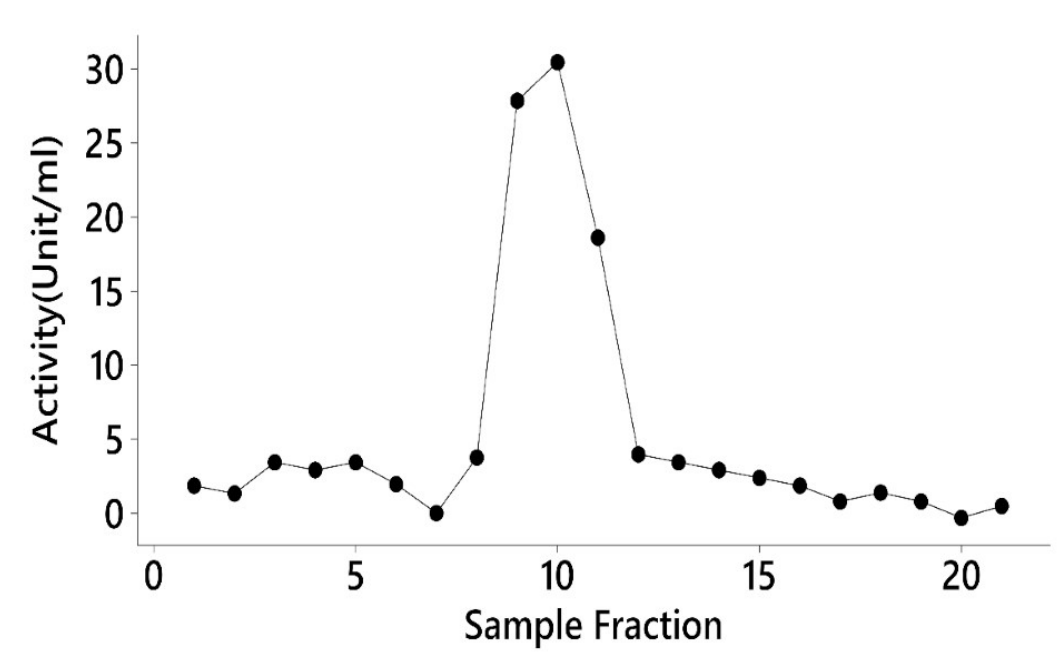

b

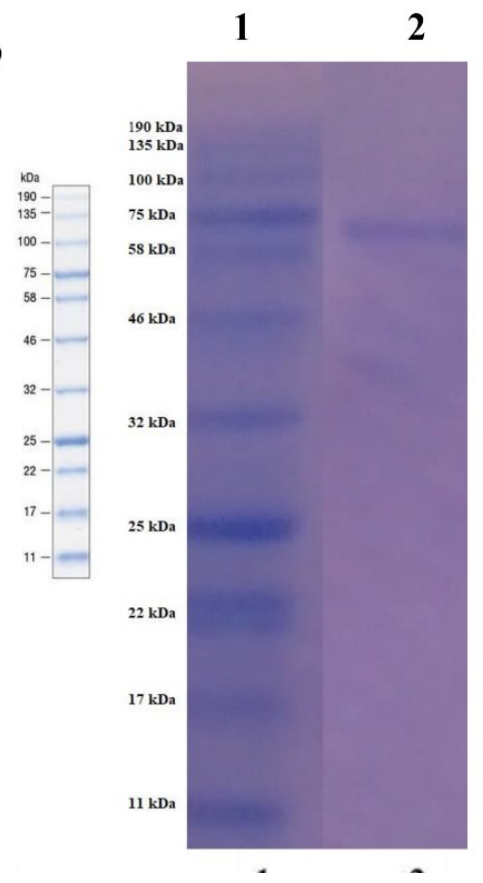

Fig. 4. Elution profile and SDS-PAGE analysis. A: Enzyme activity of different fraction after DEAE-Cellulose anion exchange chromatography, B: SDS-PAGE of purified alpha amylase from A. tengchongensis RA1-2-1; Lane 1: Molecular marker, Lane 2: Purified Enzyme 

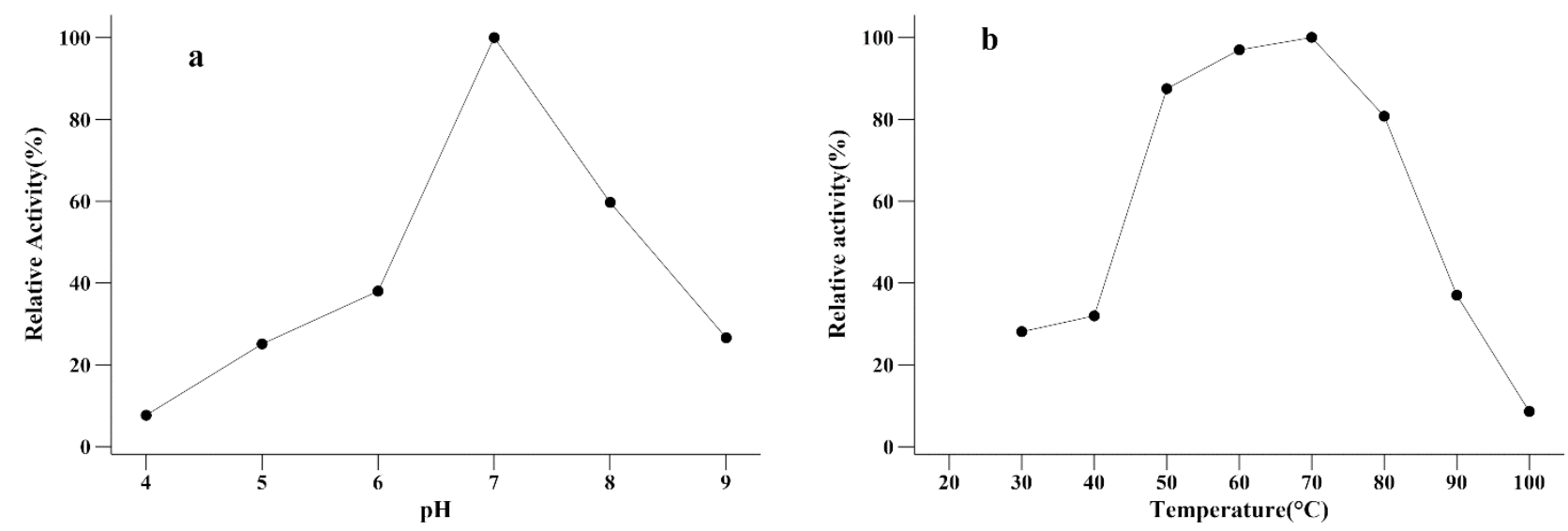

Fig. 5. Temperature and $\mathrm{pH}$ optimization. $\quad$ a: Effect of $\mathrm{pH}$ on Enzyme activity of $\mathrm{A}$. tengchongensis. .100\% activity of amylase $=1.059 \mathrm{U} / \mathrm{ml}$. b: Effect of temperature on the enzyme activity of alpha amylase from A. tengchongensis at $\mathrm{pH} 7.0 .100$ $\%$ activity

Preliminary screening was carried out in five different medium formulation to identify optimum medium for amylase production. Higher amylase activity in fermentation broth was found in Medium M3 while moderate expression was found in Medium M4 and M5. The higher production of amylase in medium M4 may be due to the presence of casein hydrolysates, yeast extract and mineral salts. The presence of complex source nitrogen such as yeast extract and meat extract has been found to enhance amylase production (Bano et al., 2011; Elmansy et al., 2018). These complex sources may contain growth factor necessary for growth of fastidious bacteria resulting in high amylase production.
This is the first report of purification and characterization of alpha amylase from Anoxybacillus tengchongensis strain. The optimum $\mathrm{pH}$ of alpha-amylase from A. tengchongensis was 7.0. The enzyme activity at $\mathrm{pH} 8.0$ was $59.68 \pm 0.63 \%$ and at $\mathrm{pH} 9.0$ was $26.6 \pm 0.73$ suggesting wide range of $\mathrm{ph}$ activity over alkaline $\mathrm{pH}$. Such types of enzyme from alkalophilic bacteria has been reported and grouped under type IV class (Yamamoto et al., 1972).

The optimum temperature was $70{ }^{\circ} \mathrm{C}$ and the enzyme activity was $84.35 \pm 0.71 \%$ at $80{ }^{\circ} \mathrm{C}$ and $38.65 \pm 1.34 \%$ at $90{ }^{\circ} \mathrm{C}$.
Fitted Exponential Line Plot $\left(60^{\circ}\right)$ Relative activity $=100 * \exp (-0.00436204 *$ 'Time'

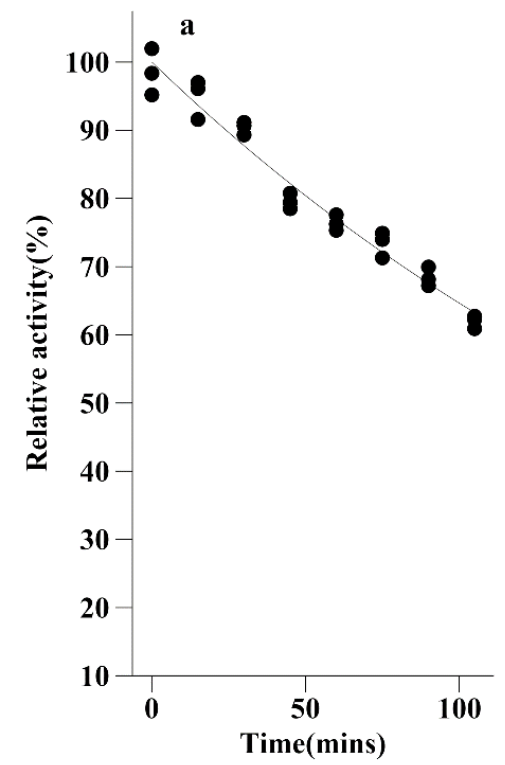

Fitted Exponential Line Plot $\left(70^{\circ} \mathrm{C}\right)$ Relative activity $=100 * \exp (-0.00754279 *$ 'Time'

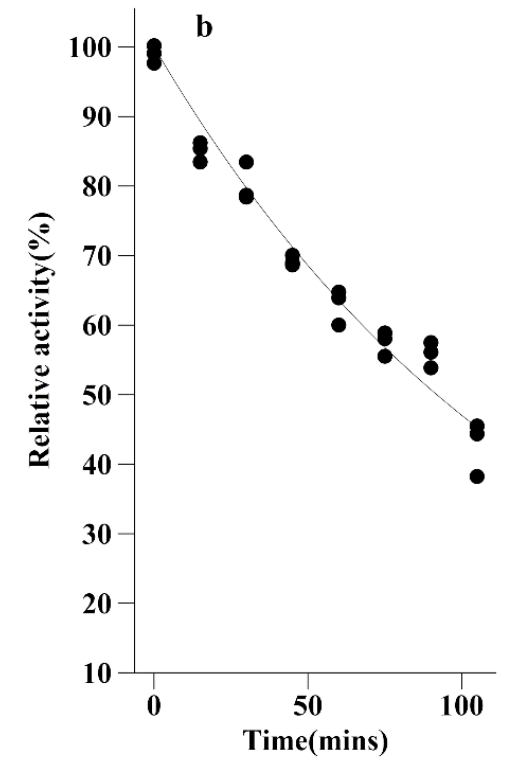

Fitted Exponential Line Plot $\left(80^{\circ} \mathrm{C}\right)$
Relative activity $=100 * \exp \left(-0.0133398 * '{ }^{2}\right.$ 'Time'

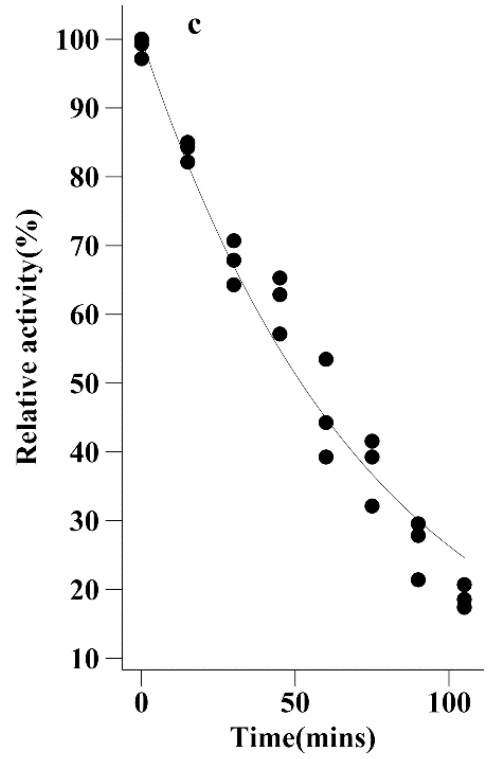

Fig. 6. Thermostability of alpha amylase from A. tengchongensis RA1-2-1 at different temperatures. Enzyme activity at 0 hour was considered as $100 \%$ activity. The half-life of enzyme was $51.96 \mathrm{~min}$ at $80{ }^{\circ} \mathrm{C}$. 
This showed that the enzyme is active over a wide temperature. The enzyme was thermostable with half-life of $51.96 \mathrm{~min}$ at $80{ }^{\circ} \mathrm{C}$. Although the optimum growth of $A$. tengchongensis was $50{ }^{\circ} \mathrm{C}$, the enzyme optimum was at higher temperature of $70{ }^{\circ} \mathrm{C}$. It has been demonstrated that there is no obligatory relationship between thermophilic properties of bacteria and thermostability properties of the enzyme (Am et al., 1978). Optimum $\mathrm{pH}$ and temperature for the strain was similar to other reported values: $\mathrm{pH} 7.0$ and temperature $80{ }^{\circ} \mathrm{C}$ for Anoxybacillus flavithermus (Veysi Okumus, 2015), pH 8.0 and $80{ }^{\circ} \mathrm{C}$, Anoxybacillus flavithermus (Agüloğlu Fincan et al., 2014) and ph 7.0 and $55^{\circ} \mathrm{C}$ for Anoxybacillus rupiences (Bhavtosh A. Kikani et al., 2020). The range of $\mathrm{pH}$ over alkaline $\mathrm{pH}$ and temperature stability make the enzyme suitable for application in detergent and textile industries .

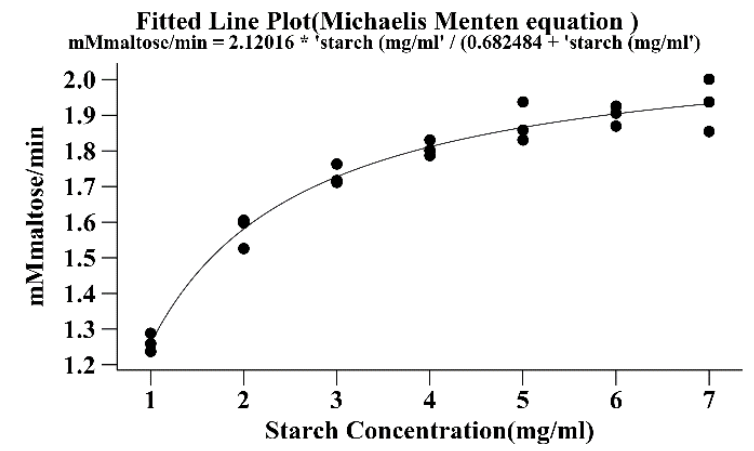

Fig. 7. Kinetics of alpha amylase from $A$. tengchongensis RA 1-2-1. The data was fit into Michaels Menten equation using nonlinear regression method. Estimated $\mathrm{Km}=0.68$ $\mathrm{mg} / \mathrm{ml}$.

SDS-PAGE result showed that the molecular mass of $A$. tengchongensis RA1-2-1 alpha amylase was $69 \mathrm{kDa}$. This is the first report of experimental calculation of molecular mass of $A$. tengchongensis. The observed molecular mass of alphaamylase from $A$. tengchongensis RA1-2-1 is higher than other closely related Anoxybacillus species: A. rupiensis TS-4 :48 kDa ( Kikani et al., 2020) ; A.beppuensis :43 kDa (B. A. Kikani \& Singh, 2012) and A.flavithrmus: 60 kDa (Agüloğlu Fincan et al., 2014).

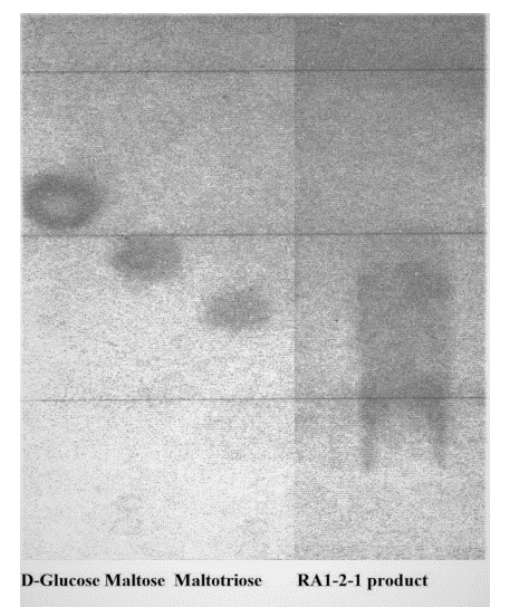

Fig. 8. TLC of the hydrolysis product of amylase from A. tengchongensis RA1-2-1 with soluble potato starch as substrate. Lane 1: D-Glucose, 2: Maltose, 3: Maltotriose, 4: Hydrolysis product after 1-hour incubation

The $K_{m}$ value of the enzyme was calculated to be $0.68 \mathrm{mg} / \mathrm{ml}$ for soluble starch as substrate. $\mathrm{K}_{\mathrm{m}}$ value $A$ noxybacillus alphaamylase have been reported earlier : $0.58 \mathrm{mg} / \mathrm{ml}$ for Anoxybacillus rupiensis TS $-4,0.5 \mathrm{mg} / \mathrm{ml}$ for A. beppuenisis (Bhavtosh A. Kikani et al., 2020), This value is also comparable to other reported value for commercially important amylase source (Bacillus licheniformis, $\mathrm{K}_{\mathrm{m}}$ : $0.9 \mathrm{mg} / \mathrm{ml}$ for Bacillus amyloliquefaciens BH072 (Ivanova et al., 1993), , $\mathrm{K}_{\mathrm{m}}: 4.27 \mathrm{mg} / \mathrm{ml}$ for Bacillus amyloliquefaciens (Du et al., 2018) and $\mathrm{K}_{\mathrm{m}}: 2.68 \mathrm{mg} / \mathrm{ml}$ for Bacillus subtilis (Bano et al., 2011). Lower $\mathrm{K}_{\mathrm{m}}$ value reflects the higher affinity of amylase of $A$. tengchongensis RA1-2-1 for soluble potato starch.

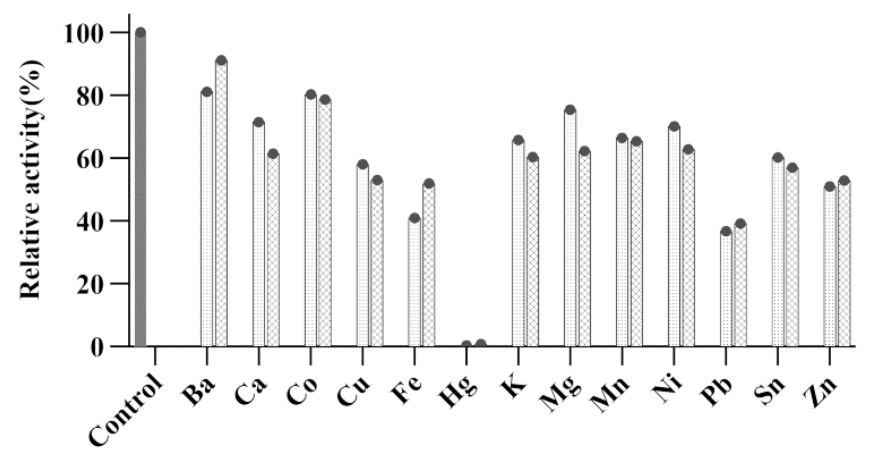

Fig. 9. Effect different metal ions on enzyme activity. The stock enzyme solution was mixed with different metal salt solution to make final concentration of $1 \mathrm{mM}$ and $10 \mathrm{mM}$ in buffered solution of $\mathrm{pH} 6.0$.

The A. tengchogensis RA1-2-1 alpha-amylase showed significant increase in enzyme in the range of $1 \mathrm{mM}-10 \mathrm{mM}$ for $\mathrm{Ba}^{2+}, \mathrm{Fe}^{2+}$ and $\mathrm{Zn}^{2+}$ ions. The enzyme showed significant inhibition for $\mathrm{Ca}^{2+}, \mathrm{Cu}^{2+}, \mathrm{Mg}^{2+}$ and $\mathrm{K}^{+}$within the concentration range studied The presence of metal ions $\mathrm{Co}^{2+}$, $\mathrm{Mn}^{2+}, \mathrm{Ni}^{2+}, \mathrm{Sn}^{2+}$ and $\mathrm{Pb}^{2+}$ did not show significant change in activity. $\mathrm{Hg}^{2+}$ was completely inhibited at both concentrations. Such complete inhibition of alpha-amylase at $1 \mathrm{mM} \mathrm{Hg}^{2+}$ concentration has been reported in amylase from Aspergillus oryzae (Bhanja Dey \& Banerjee, 2015) and $B$. amyloliquefaciens (Demirkan et al., 2005)). Due to its salt tolerance properties alpha amylase from A. tengchongensis RA1-2-1 could be a candidate for industrial enzymes. The genes for the enzymes can be cloned in suitable host for desirable modification, purification and expression of the enzyme.

\section{Conclusion}

The liquefying maltogenic enzyme was found to be highly thermostable with half-life of $51.96 \mathrm{~min}$ at $80^{\circ} \mathrm{C}$. The enzyme was tolerant to significant metal inhibition except $\mathrm{Hg}^{+}$. The enzyme was active over a wide $\mathrm{pH}$ range of 6.0 -9.0. The enzyme could be a potential candidate for application in food processing industries.

\section{Acknowledgment}

This research work was funded by International Foundation for Science (IFS), Sweden and Organization for the 
Prohibition of Chemical Weapons (OPCW) through project ID: F/5785-1.

\section{References}

Agüloğlu Fincan, S., Enez, B., Özdemir, S., \& Matpan Bekler, F. (2014). Purification and characterization of thermostable $\alpha$-amylase from thermophilic Anoxybacillus flavithermus. Carbohydrate Polymers, 102(1), 144-150. https://doi.org/10.1016/j.carbpol.2013.10.048

Am, T., Amylases, A., Synthesis, A. E. E., Biosynthesis, A., Induction, C., Repression, C., \& Aspects, D. G. (1978). Bacterial a-Amylases M. B. INGLE. 24.

Andersson, E., Johansson, A. C., \& Hahn-Hägerdal, B. (1985). $\alpha$-amylase production in aqueous two-phase systems with Bacillus subtilis. Enzyme and Microbial Technology. https://doi.org/10.1016/01410229(85)90112-7

Bano, S., Qader, S. A. U., Aman, A., Syed, M. N., \& Azhar, A. (2011). Purification and characterization of novel $\alpha-$ amylase from bacillus subtilis KIBGE HAS. AAPS PharmSciTech. https://doi.org/10.1208/s12249-0119586-1

Bernfeld, P. (1955). [17] Amylases, $\alpha$ and $\beta$. Methods in Enzymology. https://doi.org/10.1016/0076$6879(55) 01021-5$

Bhanja Dey, T., \& Banerjee, R. (2015). Purification, biochemical characterization and application of $\alpha$ amylase produced by Aspergillus oryzae IFO-30103. Biocatalysis and Agricultural Biotechnology, 4(1), 8390.

https://doi.org/https://doi.org/10.1016/j.bcab.2014.10.00 $\underline{2}$

Demirkan, E. S., Mikami, B., Adachi, M., Higasa, T., \& Utsumi, S. (2005). $\alpha$-Amylase from B. amyloliquefaciens: purification, characterization, raw starch degradation and expression in E. coli. Process Biochemistry, 40(8), 2629-2636. https://doi.org/https://doi.org/10.1016/j.procbio.2004.08 .015

Du, R., Song, Q., Zhang, Q., Zhao, F., Kim, R. C., Zhou, Z., \& Han, Y. (2018). Purification and characterization of novel thermostable and $\mathrm{Ca}$-independent $\alpha$-amylase produced by Bacillus amyloliquefaciens BH072. International Journal of Biological Macromolecules. https://doi.org/10.1016/j.ijbiomac.2018.05.004

Dumorné, K., Córdova, D. C., Astorga-Eló, M., \& Renganathan, P. (2017). Extremozymes: A Potential Source for Industrial Applications. Journal of Microbiology and Biotechnology, 27(4), 649-659. https://doi.org/10.4014/jmb.1611.11006

Elmansy, E. A., Asker, M. S., El-Kady, E. M., Hassanein, S. M., \& El-Beih, F. M. (2018). Production and optimization of $\alpha$-amylase from thermo-halophilic bacteria isolated from different local marine environments.Bulletin of the National Research Centre, 42(1).https://doi.org/10.1186/s42269-018-0033-2

Fincan, S. A., \& Enez, B. (2014). Production, purification, and characterization of thermostable a-amylase from thermophilic Geobacillus stearothermophilus. Starch/Staerke. https://doi.org/10.1002/star.201200279
Finore, I., Kasavi, C., Poli, A., Romano, I., Oner, E. T., Kirdar, B., Dipasquale, L., Nicolaus, B., \& Lama, L. (2011). Purification, biochemical characterization and gene sequencing of a thermostable raw starch digesting $\alpha$-amylase from Geobacillus thermoleovorans subsp. stromboliensis subsp. nov. World Journal of Microbiology and Biotechnology. https://doi.org/10.1007/s11274-011-0715-5

Hansen, S. A. (1975). Thin-layer chromatographic method for the identification of mono-, di- and trisaccharides. Journal of Chromatography $A$. https://doi.org/10.1016/S0021-9673(00)82770-3

Heinen, W., Lauwers, A. M., \& Mulders, J. W. (1982). Bacillus flavothermus, a newly isolated facultative thermophile. Antonie van Leeuwenhoek, 48(3), 265 272. https://doi.org/10.1007/BF00400386

Ivanova, V. N., Dobreva, E. P., \& Emanuilova, E. I. (1993). Purification and characterization of a thermostable alpha-amylase from Bacillus licheniformis. Journal of Biotechnology. https://doi.org/10.1016/01681656(93)90176-N

Kikani, B. A., \& Singh, S. P. (2012). The stability and thermodynamic parameters of a very thermostable and calcium-independent $\alpha$-amylase from a newly isolated bacterium, Anoxybacillus beppuensis TSSC-1. Process Biochemistry, 47(12), 1791-1798. https://doi.org/10.1016/j.procbio.2012.06.005

Kikani, Bhavtosh A., Kourien, S., \& Rathod, U. (2020). Stability and Thermodynamic Attributes of Starch Hydrolyzing $\alpha$-Amylase of Anoxybacillus rupiensis TS4. Starch/Staerke, 72(1-2), 1-10. https://doi.org/10.1002/star.201900105

Kindle, K. L. (1983). Characteristics and production of thermostable $\alpha$-amylase. Applied Biochemistry and Biotechnology, 8(2), 153-170. https://doi.org/10.1007/BF02778096

Laemmli, U. K. (1970). Cleavage of structural proteins during the assembly of the head of bacteriophage T4. Nature. https://doi.org/10.1038/227680a0

Lowry, O. H., Rosebrough, N. J., Farr, A. L., \& Randall, R. J. (1951). Protein measurement with the Folin phenol reagent. The Journal of Biological Chemistry. https://doi.org/10.1016/0922-338X(96)89160-4

Pfueller, S. L., \& Elliott, W. H. (1969). The Extracellular $\alpha$ Amylase of Bacillus stearothermophilus. Journal of Biological Chemistry, 244(1), 48-54. http://www.jbc.org/content/244/1/48.abstract

Upton, M. E., \& Fogarty, W. M. (1977). Production and purification of thermostable amylase and protease of Thermomonospora viridis. Applied and Environmental Microbiology. https://doi.org/10.1128/aem.33.1.5964.1977

Veysi Okumus, S. O. (2015). Isolation of a Novel Thermophilic Anoxybacillus flavithermus SO-13, Production, Characterization and Industrial Applications of its Thermostable alpha-Amylase. Journal of Bioprocessing \& Biotechniques, 05(07). https://doi.org/10.4172/2155-9821.1000237

Yamamoto, M., Tanaka, Y., \& Horikoshi, K. (1972). Alkaline Amylases of Alkalophilic Bacteria. Agricultural and Biological Chemistry, 36(10), 18191823. https://doi.org/10.1080/00021369.1972.10860480 Zhang, C. M., Huang, X. W., Pan, W. Z., Zhang, J., Wei, K. 
Timilsina et al.,: J. Food Sci. Technol. Nepal, Vol. 12 (49 - 58), 2020

B., Klenk, H. P., Tang, S. K., Li, W. J., \& Zhang, K. Q. (2011). Anoxybacillus tengchongensis sp. nov. and Anoxybacillus eryuanensis sp. nov., facultatively anaerobic, alkalitolerant bacteria from hot springs. International Journal of Systematic and Evolutionary Microbiology, 61(1), 118-122.

https://doi.org/10.1099/ijs.0.020834-0

Zwietering, M. H., Jongenburger, I., Rombouts, F. M., \& Van't Riet, K. (1990). Modeling of the bacterial growth curve. Applied and Environmental Microbiology, 56(6), 1875-1881. https://doi.org/10.1128/aem.56.6.1875-

1881.1990 